\title{
Characterization of free amino acids, bacteria and fungi in size-segregated atmospheric aerosols in boreal forest: seasonal patterns, abundances and size distributions
}

\author{
Aku Helin ${ }^{1}$, Outi-Maaria Sietiö ${ }^{2}$, Jussi Heinonsalo ${ }^{2}$, Jaana Bäck ${ }^{3}$, Marja-Liisa Riekkola ${ }^{1}$, and Jevgeni Parshintsev ${ }^{1}$ \\ ${ }^{1}$ Department of Chemistry, P.O. Box 55, University of Helsinki, 00014 Helsinki, Finland \\ ${ }^{2}$ Division of Microbiology and Biotechnology, Department of Food and Environmental Sciences, P.O. Box 56, \\ University of Helsinki, 00014 Helsinki, Finland \\ ${ }^{3}$ Department of Forest Sciences, P.O. Box 27, University of Helsinki, 00014 Helsinki, Finland
}

Correspondence to: Jevgeni Parshintsev (evgeny.parshintsev@helsinki.fi)

Received: 3 July 2017 - Discussion started: 21 July 2017

Revised: 20 September 2017 - Accepted: 5 October 2017 - Published: 6 November 2017

\begin{abstract}
Primary biological aerosol particles (PBAPs) are ubiquitous in the atmosphere and constitute $\sim 30 \%$ of atmospheric aerosol particle mass in sizes $>1 \mu \mathrm{m}$. PBAP components, such as bacteria, fungi and pollen, may affect the climate by acting as cloud-active particles, thus having an effect on cloud and precipitation formation processes. In this study, size-segregated aerosol samples $(<1.0,1-2.5,2.5-$ 10 and $>10 \mu \mathrm{m}$ ) were collected in boreal forest (Hyytiälä, Finland) during a 9-month period covering all seasons and analysed for free amino acids (FAAs), DNA concentration and microorganism (bacteria, Pseudomonas and fungi). Measurements were performed using tandem mass spectrometry, spectrophotometry and qPCR, respectively. Meteorological parameters and statistical analysis were used to study their atmospheric implication for results. Distinct annual patterns of PBAP components were observed, late spring and autumn being seasons of dominant occurrence. Elevated abundances of FAAs and bacteria were observed during the local pollen season, whereas fungi were observed at the highest level during autumn. Meteorological parameters such as air and soil temperature, radiation and rainfall were observed to possess a close relationship with PBAP abundances on an annual scale.
\end{abstract}

\section{Introduction}

Primary biological aerosol particles (PBAPs) are emitted directly from the biosphere into the atmosphere (Després et al., 2012; Fröhlich-Nowoisky et al., 2016). PBAPs are released from multiple sources, such as soil, vegetation and oceans, and they include, for example, pollen, plant fragments, spores, bacteria, algae and viruses. In recent years, the abundance and dispersal of microorganisms in the atmosphere have attracted more and more interest, mainly due to the underestimation of their abundance and their possible atmospheric impact (Jaenicke, 2005; Morris et al., 2011; Deguillaume et al., 2008; Burrows et al., 2009b; Estillore et al., 2016). It is estimated that globally PBAPs constitute $\sim 30 \%$ of aerosol particles mass in the particles sized $>1 \mu \mathrm{m}$ in urban and rural air (Fröhlich-Nowoisky et al., 2016). This fraction can be much higher $(\sim 80 \%)$ in the tropical forest areas (Pöschl et al., 2010; Elbert et al., 2007), and interestingly even up to $65 \%$ at boreal forest during pollen season (Manninen et al., 2014). These high percentages provide the basis for assumptions that PBAPs may play an important role in the atmosphere by affecting cloud and precipitation formation processes by acting as cloud and ice nuclei (Huffman et al., 2013; Burrows et al., 2009a, b; Després et al., 2012; Fröhlich-Nowoisky et al., 2016). Thus, to clarify their atmospheric transport and ecosystem interactions, PBAPs' chemical and microbial constituents need more characterization and identification. 
PBAPs have been studied by using a variety of techniques (Georgakopoulos et al., 2008), but cultivation and microscopy have been frequently employed for the elucidation of microorganisms in aerosols (Manninen et al., 2014; Després et al., 2012). Nowadays, molecular genetic analysis techniques, such as quantitative polymerase chain reaction (qPCR) or next-generation sequencing (NGS), have gained ground, because they provide information not only on the viable and cultivable cells but also on uncultivable, dead or fragments of plant and animal cells (Després et al., 2012). Alternative approach to determine particles of biological origin is based on chemical tracer techniques (Bauer et al., 2008; Gosselin et al., 2016; Hock et al., 2008; Schneider et al., 2011; Zhang et al., 2010; Staton et al., 2015; Rathnayake et al., 2017). The benefit of chemical tracers, such as carbohydrates, proteins/amino acids and lipids, is their applicability to quantitative analysis, while their main disadvantage is inability to identify different biological species. Specific tracers have been used to estimate the total number of PBAPs in the atmosphere (Gosselin et al., 2016; Hock et al., 2008; Schneider et al., 2011; Zhu et al., 2015).

Biologically derived amino acids are non-volatile and hygroscopic compounds that are mainly found in the condensed phases in the atmosphere (Matos et al., 2016; Samy et al., 2013; Zhang and Anastasio, 2003). They are present in aerosols either in the combined form (proteins and peptides) or as free amino acids (FAAs), and they are emitted either from biogenic sources or formed from the degradation of proteinaceous material (Milne and Zika, 1993; Matos et al., 2016). Due to their close relationship with PBAPs, amino acids can be used as a biomarker for an overall estimation of biomass in aerosols (Hock et al., 2008; Schneider et al., 2011).

In this study size-segregated aerosol samples were collected in boreal forest during a 9-month period. Aerosol samples were analysed for DNA concentration, microorganism DNA (bacteria, Pseudomonas and fungi) and FAAs. The annual concentration and size distribution variation of microorganisms and FAAs were investigated in detail in order to understand their potential sources. A correlation study between the PBAP components and meteorological parameters was carried out. Our objective was to gain further information about the abundances of PBAPs in different particle size fractions at the boreal forest region and to understand their biosphere-atmosphere interactions better.

\section{Experimental section}

\subsection{Materials and reagents}

Detailed information on materials and reagents is presented in the Supplement.

\subsection{Aerosol sampling}

The aerosol samples were collected in a Scots pine forest between February and October 2014 at the SMEAR II station (Station for Measuring Forest Ecosystem-Atmosphere Relations) in Hyytiälä, Finland (Hari and Kulmala, 2005). A Dekati $\mathrm{PM}_{10}$ impactor was used for the sampling of four particle size fractions $(<1.0,1-2.5,2.5-10$ and $>10 \mu \mathrm{m})$ below the canopy. The sampling flow rate was on average $30 \mathrm{~L} \mathrm{~min}^{-1}$ and the collection time was from 1 to 4 days (sampling volume $76-144 \mathrm{~m}^{3}$ ). The collection filters were $25 \mathrm{~mm}$ polycarbonate membranes (Whatman Nuclepore) for the three largest particle size fractions. To prevent particles from bouncing, membranes were smeared with diluted Apiezon L vacuum grease. The smallest size fraction $(<$ $1.0 \mu \mathrm{m}$ ) was collected on a $47 \mathrm{~mm}$ Teflon filter (Gelman Sciences) with $2 \mu \mathrm{m}$ pore size. After sampling, the filters were dried and weighed. The sampling procedure is described in more details in Laakso et al. (2003). After gravimetric analysis, the filters were placed inside a closed polystyrene Petri dish, covered with aluminium foil and stored at $-20^{\circ} \mathrm{C}$.

Two sets of aerosol samples were collected in consecutive days, so that the sampling dates were close to each other (Table S1 in the Supplement). The first set of aerosol samples was analysed for DNA and microorganisms (set A) and the other set for free amino acids (set B). For molecular biological analysis only particles larger than $1 \mu \mathrm{m}$ were selected because smaller fractions were suspected to contain only virus particles and fragmented DNA.

\subsection{Determination of amino acids}

After ultrasound-assisted extraction, free amino acids were determined by liquid chromatography-tandem mass spectrometry. Detailed information about the validation and quality control of the analytical method is presented in the Supplement, Fig. S1 and Tables S2-S4.

\subsection{Extraction of DNA}

Total nucleic acids were extracted from the collection filters with a commercial DNA extraction kit (PowerWater DNA Isolation Kit, MoBio Laboratories, USA) with slight modification (see Supplement). The DNA concentration and purity was measured spectrophotometrically at 260 and $280 \mathrm{~nm}$ with NanoDrop ND-1000 (Thermo Scientific, USA). The DNA samples were stored at $-20^{\circ} \mathrm{C}$ prior to qPCR.

\subsection{DNA amplification}

The bacterial and fungal DNA amounts of the filter samples were quantified with qPCR using target-specific primer pairs, Eub338F and Eub518R, and FF390 and FR1 (Table S5) (Fierer et al., 2005; Vainio and Hantula, 2000). In addition, genus-specific primers, Eub338F and PseudoR, were utilized 
to detect the bacteria belonging to the genus Pseudomonas (Purohit et al., 2003).

In the bacterial and Pseudomonas-specific qPCR reactions, standard curves were generated with DNA extracted from Pseudomonas fluorescens H-27 (Hambi culture collection, University of Helsinki), and for the fungal-specific qPCR, the DNA from the newly whole-genome-sequenced Phlebia radiata FBCC43 (genome size 40.92 Mb, FBCC culture collection, University of Helsinki) was used (Kuuskeri et al., 2016). When converting the copy number of the samples into bacterial cells (colony-forming units), all bacteria were assumed to contain average of three gene copies of ribosomal 16S DNA per cell, and bacteria belonging to genus Pseudomonas were assumed to contain five gene copies of $16 \mathrm{~S}$ rDNA in a cell (Stoddard et al., 2014). According to Fröhlich-Nowoisky et al. (2009), the majority of the fungal DNA detected during summer and autumn is from fungal species belonging to Basidiomycota. Based on previous results (Fröhlich-Nowoisky et al., 2009, 2012), we have assumed that most the fungal DNA collected on our filters is also derived from basidiomycete fungi. Because only a few $18 \mathrm{~S}$ rDNA regions of fungi are fully annotated, we have selected the $P$. radiata as a model basidiomycete fungus and calculated the gene copy numbers to fungal cells based on the assumption that all fungi in this experiment have approximately the same number of $18 \mathrm{~S}$ rDNA gene copies as this fungus has (Kuuskeri et al., 2016).

\subsection{Additional background data and back-trajectory analysis}

Meteorological variables, gas fluxes and atmospheric gases are continuously measured at the SMEAR II and the data are available from the AVAA portal (Junninen et al., 2009). Half-hourly averaged data from the portal were further averaged according to each sampling time period by using arithmetic mean. These averaged values were used in statistical analyses. The selected variables were air (AT) and soil surface temperature (SST), soil surface water content (SSWC), wind speed (WS) and direction (WD), gross primary production (GPP), $\mathrm{CO}, \mathrm{CO}_{2}$ and ozone concentration, photosynthetically active radiation (PAR), UV-A and UV-B radiation, and relative humidity $(\mathrm{RH})$. In addition, rainfall was averaged according to different time periods as follows: $72 \mathrm{~h}$ before sampling (BSR), during sampling (DSR) and $168 \mathrm{~h}$ after sampling (ASR).

Backward air mass trajectories were calculated using the HYSPLIT (Hybrid Single-Particle Lagrangian Integrated Trajectory) transport and dispersion model from NOAA Air Resources Laboratory to estimate the origin and transport route of aerosol particles (Draxler and Hess, 1998; Stein et al., 2015; Rolph, 2003). For the calculations, meteorological data from the Global Data Assimilation System (GDAS, $1^{\circ}$, global, 2006-present) were used. The backward air mass trajectories were modelled $48 \mathrm{~h}$ back time during the whole period of sampling, using a resolution of $12 \mathrm{~h}$.

\subsection{Statistical analysis}

For analysing the importance of the seasonality and the aerosol filter size, permutational multivariate analysis of variance (PERMANOVA) was performed for the presence/absence of transformed amino acid data. The PERMANOVA was performed with the adonis function of the vegan package (Oksanen et al., 2016) with 999 permutations, and the amino acid data were set as response variables while sampling month and aerosol filter size were set as explanatory variables. One-way analysis of variance (ANOVA) was performed to the fungal, bacterial and Pseudomonas gene copy numbers individually with the aov function from the stats package (R Core Team, 2016) in order to study the effect of seasonality and aerosol filter size. Prior to performing ANOVA the normal distribution of each residual was checked individually with shapiro.test function, and all the gene copy number data were log-normalized. The Spearman's correlations between the FAA and microorganisms concentrations with meteorological variables were calculated using the rcorr function of the Hmisc package (Harrell, 2016) and visualized with the corrplot package (Wei and Simko, 2016) showing only correlations with statistical significance $(p \leq 0.05)$.

\section{Results and discussion}

\subsection{General characteristics}

The average concentration and range of each component measured in different particle size fractions at the boreal forest site are presented in Tables 1 and S6. The lowest concentration levels of FAA and total DNA were measured during winter and highest during late spring (Figs. 1 and S2). The total amount of extracted DNA was highest from May to June (up to $48 \mathrm{ng} \mathrm{m}^{-3}$ ) and from September to October (up to $14 \mathrm{ng} \mathrm{m}^{-3}$ ). The FAA concentration in total particles was highest in late May (up to $751 \mathrm{ng} \mathrm{m}^{-3}$ ) and in September (up to $35 \mathrm{ng} \mathrm{m}^{-3}$ ). A common trend in both total DNA and FAA concentrations was a maximum in spring and a secondary smaller maximum in autumn. Similarly, the highest PM concentration in total particles was recorded during late spring and autumn (Fig. S3), a pattern which has also been previously observed at the same location (Laakso et al., 2003; Manninen et al., 2014). The measured DNA concentrations agreed with those obtained for $\mathrm{PM}_{2.5}$ samples at a rural mountain site in Germany, where the DNA concentration was in the range $1.7-4.2 \mathrm{ng} \mathrm{m}^{-3}$ (Després et al., 2007). Also, the observed FAA concentrations were in the same order of magnitude as those observed in other rural and semi-urban locations (Zhang and Anastasio, 2003; Zhang et al., 2002; Samy et al., 2011, 2013). For example, at two rural sites in the US 
Table 1. Average ( \pm SD) concentration and range of each component measured and the number of filter samples $(n)$ analysed in total.

\begin{tabular}{|c|c|c|c|c|c|}
\hline Component & $<1 \mu \mathrm{m}$ & $1-2.5 \mu \mathrm{m}$ & $2.5-10 \mu \mathrm{m}$ & $>10 \mu \mathrm{m}$ & Total particles \\
\hline $\begin{array}{l}\mathrm{PM}\left(\mu \mathrm{g} \mathrm{m}^{-3}\right) \\
n=138\end{array}$ & $\begin{array}{l}5.9 \pm 4.1 \\
(1.0-18.1)\end{array}$ & $\begin{array}{l}2.1 \pm 2.3 \\
(0.2-11.9)\end{array}$ & $\begin{array}{l}2.4 \pm 3.2 \\
(0.2-15.9)\end{array}$ & $\begin{array}{l}2.1 \pm 3.5 \\
(0.03-17.4)\end{array}$ & $\begin{array}{l}12.3 \pm 12.2 \\
(2.2-63.3)\end{array}$ \\
\hline $\begin{array}{l}\text { FAA }\left(\mathrm{ng} \mathrm{m}^{-3}\right) \\
n=69\end{array}$ & $\begin{array}{l}5.22 \pm 10.11 \\
(<\text { LOQ-41.21) }\end{array}$ & $\begin{array}{l}10.95 \pm 31.54 \\
(<\text { LOQ- } \\
120.24)\end{array}$ & $\begin{array}{l}18.45 \pm 53.55 \\
(<\text { LOQ- } \\
224.92)\end{array}$ & $\begin{array}{l}27.62 \pm 85.71 \\
(0.04-364.65)\end{array}$ & $\begin{array}{l}57.91 \pm 174.17 \\
(1.13-751.01)\end{array}$ \\
\hline $\begin{array}{l}\text { DNA }\left(\mathrm{ng} \mathrm{m}^{-3}\right) \\
n=51\end{array}$ & - & $\begin{array}{l}5.16 \pm 5.20 \\
(<\mathrm{LOQ}-18.56)\end{array}$ & $\begin{array}{l}1.99 \pm 3.47 \\
(0.002-14.67)\end{array}$ & $\begin{array}{l}2.18 \pm 3.76 \\
(<\text { LOQ-14.80) }\end{array}$ & $\begin{array}{l}8.60 \pm 11.41 \\
(0.24-48.04)\end{array}$ \\
\hline $\begin{array}{l}\text { Bacteria }\left(\text { cells } \mathrm{m}^{-3}\right) \\
n=51\end{array}$ & - & $\begin{array}{l}2811 \pm 6619 \\
(17-27551)\end{array}$ & $\begin{array}{l}2171 \pm 4032 \\
(56-16746)\end{array}$ & $\begin{array}{l}1341 \pm 3424 \\
(41-14434)\end{array}$ & $\begin{array}{l}6323 \pm 13748 \\
(137-58731)\end{array}$ \\
\hline $\begin{array}{l}\text { Pseudomonas } \\
{\text { (cells } \mathrm{m}^{-3} \text { ) }}_{n=51}\end{array}$ & - & $\begin{array}{l}74 \pm 125 \\
(0.1-469)\end{array}$ & $\begin{array}{l}4 \pm 5 \\
(<\text { LOQ-14) }\end{array}$ & $\begin{array}{l}13 \pm 26 \\
(<\text { LOQ-84) }\end{array}$ & $\begin{array}{l}86 \pm 122 \\
(1-469)\end{array}$ \\
\hline $\begin{array}{l}\text { Fungi (cells } \mathrm{m}^{-3} \text { ) } \\
n=51\end{array}$ & - & $\begin{array}{l}4022 \pm 7518 \\
(2-27838)\end{array}$ & $\begin{array}{l}5579 \pm 10614 \\
(9-42667)\end{array}$ & $\begin{array}{l}648 \pm 1809 \\
(<\text { LOQ-7129) }\end{array}$ & $\begin{array}{l}10173 \pm 15622 \\
(27-55839)\end{array}$ \\
\hline
\end{tabular}
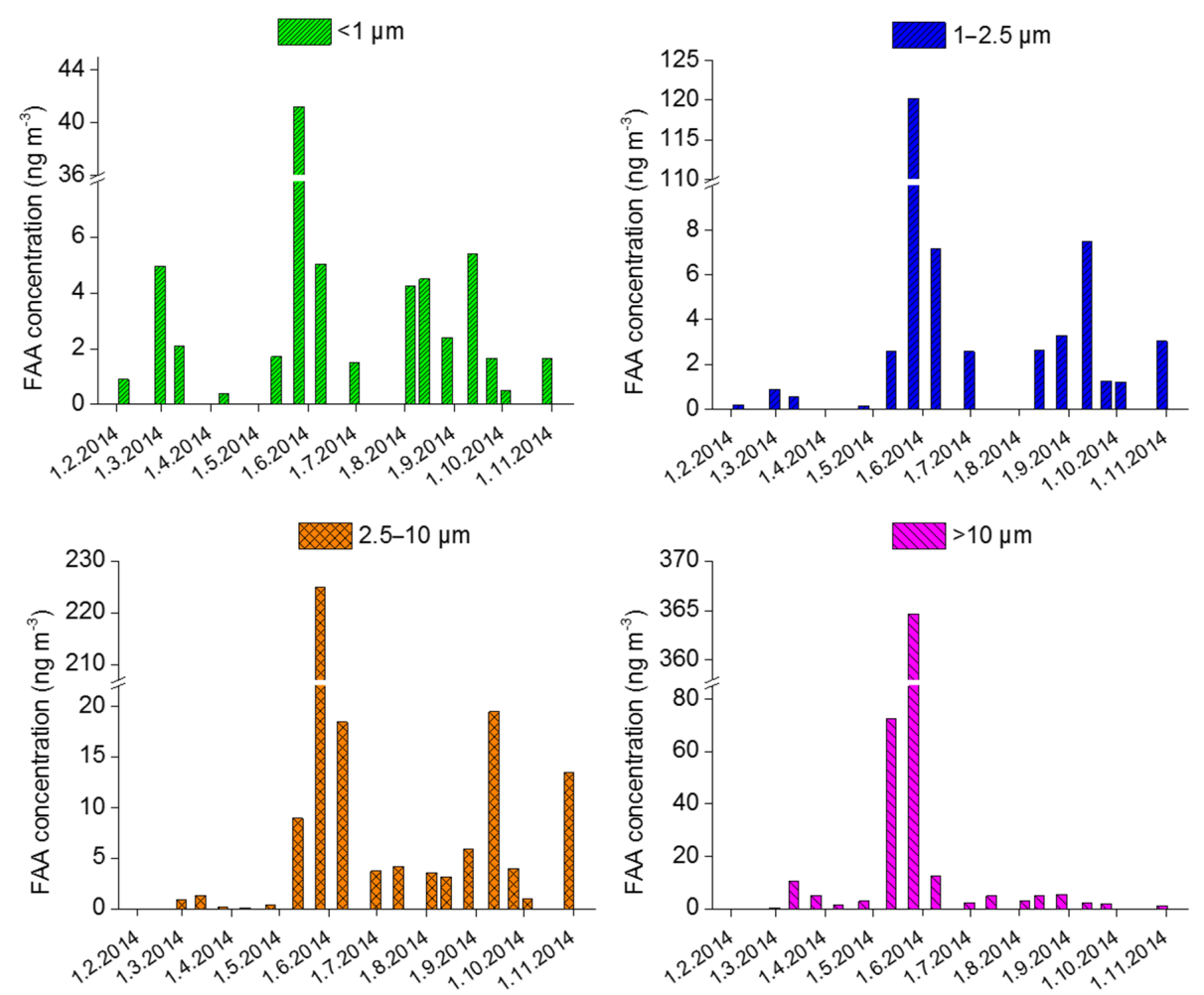

Figure 1. Free amino acid concentrations over the sampling period in different particle size fractions (date format is dd.mm.yyyy.). Note the different $y$ axis scales in panels.

the concentration of FAAs in $\mathrm{PM}_{2.5}$ samples was measured to be $22 \pm 9 \mathrm{ng} \mathrm{m}^{-3}$ during summer (Samy et al., 2011), and $59 \pm 49 \mathrm{ng} \mathrm{m}^{-3}$ (range $9-236 \mathrm{ng} \mathrm{m}^{-3}$ ) during one year study period (Zhang and Anastasio, 2003). To our knowledge, there are no studies covering DNA and FAA abundances at the boreal forest region; thus, comparison to previous results is not feasible.
Similar to the annual trend of total DNA and FAAs, the lowest concentration levels of microorganisms were detected during winter and highest during spring and autumn. However, bacterial and fungal DNA reached their maximum levels at different seasons, with bacteria peaking in late spring (Fig. 2a) and fungal DNA in late summer and autumn (Fig. 3). The bacterial DNA abundance in total particles was lower than 900 cells m$^{-3}$ during winter and early 
(a)

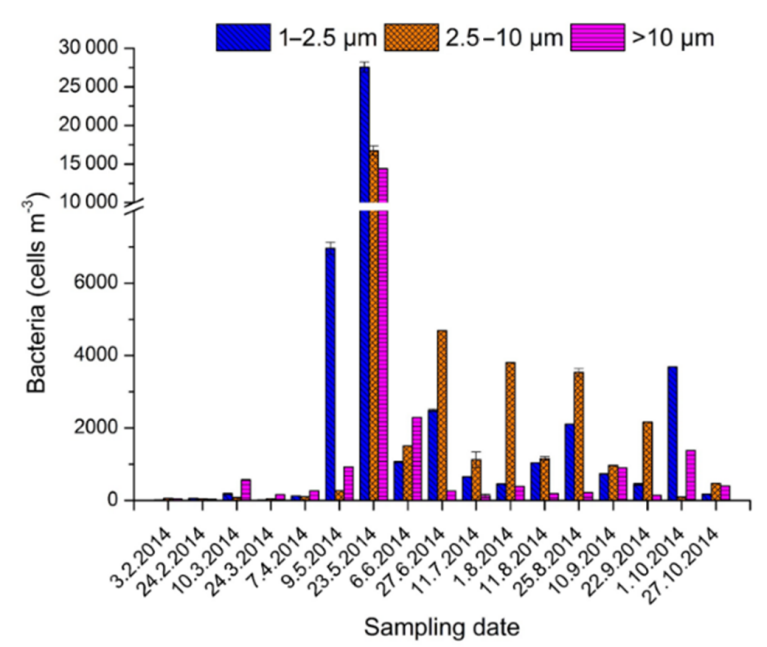

(b)

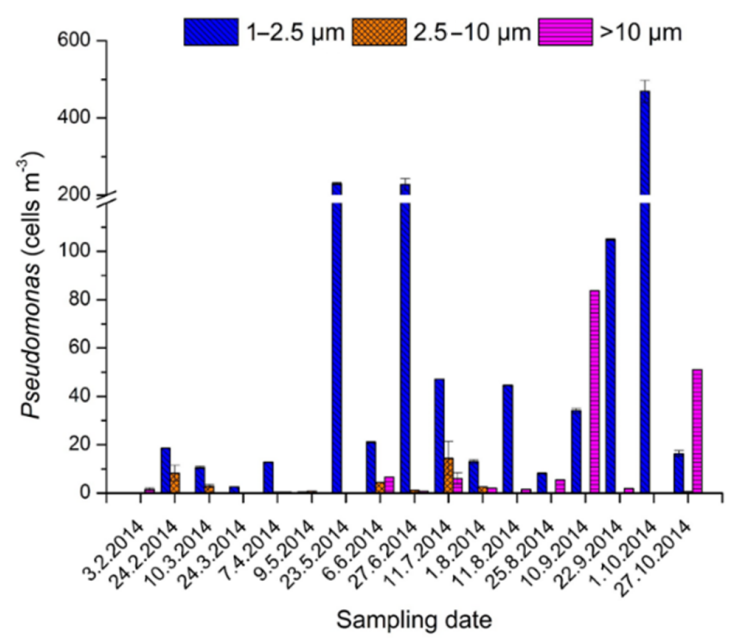

Figure 2. (a) The number of all bacterial cells over the sampling period, and (b) cells of bacteria belonging to genus Pseudomonas, detected with qPCR from the aerosol filters, specified by the particle size fractions.

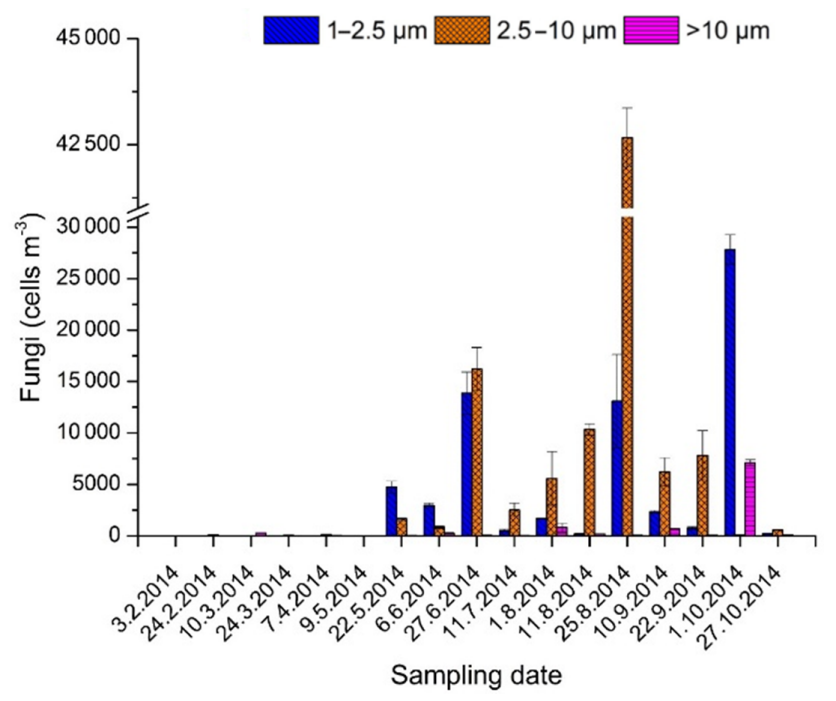

Figure 3. The number of fungal cells and spores over the sampling period, detected with qPCR from the filters of different particle size fractions.

spring, whereas in late spring the concentration peaked at 58731 cells $\mathrm{m}^{-3}$. During summer and autumn, the concentration of bacterial DNA was 1 order of magnitude lower. In contrast to the total number of bacteria, the highest amounts $\left(>200\right.$ cells $\mathrm{m}^{-3}$ ) of Pseudomonas DNA were measured in late May, late June and October (Fig. 2b). In the rest of the times, the concentration of bacteria belonging to the genus Pseudomonas was much lower, and the highest concentration levels in total particles rarely exceeded 50 cells $\mathrm{m}^{-3}$. The fungal abundance was lower than 300 cells m$^{-3}$ during winter and early spring, whereas in late spring and summer the concentrations started to increase and generally exceeded 6000 cells $\mathrm{m}^{-3}$ in total particles. The highest amounts of fungal DNA were measured in late June (30149 cells m $\left.{ }^{-3}\right)$, August ( 55839 cells m$^{-3}$ ) and early October ( 35050 cells m$^{-3}$ ). In general, the concentration levels of microorganisms vary seasonally and geographically but are estimated to be at the level of $\sim 10^{4}-10^{5}$ and $\sim 10^{4}-10^{5} \mathrm{~m}^{-3}$ for bacterial cells and fungal spores, respectively (Burrows et al., 2009b; Després et al., 2012; Spracklen and Heald, 2014). Our observations are consistent with the common trend when considering that low concentration levels are typically observed at rural locations.

\subsection{Seasonal variation and size distribution of FAAs}

In winter the amino acids were mainly accumulated in the particle size fraction $<1 \mu \mathrm{m}(\sim 74 \%$, Fig. S4a), whereas during spring the amino acids were mainly present in the largest particle size fraction $>10 \mu \mathrm{m}(\sim 77 \%)$. The highest concentrations of FAAs were observed during late spring and early summer (Fig. 1), when the local pollen season plumed. During summer, the concentrations of FAAs were relatively constant and seemingly FAAs evenly distributed in all the size fractions (Fig. S4a). In autumn they were mainly present in the particles below $10 \mu \mathrm{m}$, and they accumulated especially in the size fraction $2.5-10 \mu \mathrm{m}(\sim 51 \%)$. During autumn, there was a slight increase in the total FAA concentrations mainly due to the increase in the size fraction 2.5$10 \mu \mathrm{m}$ (Fig. 1).

Similarly, in the size distribution of individual amino acids some clear tendencies were observed (Fig. S5). The results from the PERMANOVA analysis indicated that seasonal variation explained the observed variation across the whole 
FAA data with statistical significance $(p<0.001)$. In addition, the size of the aerosol filter was a statistically significant factor for explaining the observed variation across the whole amino acid data (PERMANOVA, $p<0.001$ ). Glycine was the most dominant amino acid in the size fraction $<1 \mu \mathrm{m}$, whereas in the larger size fractions its relative abundance was much smaller (Fig. S5). On average, glycine accounted for $59 \%$ of the total FAAs in particles $<1 \mu \mathrm{m}$, followed by alanine $(10 \%)$, aspartic acid $(9 \%)$ and glutamine $(9 \%)$. In the size fraction $1-2.5 \mu \mathrm{m}$, glutamine ( $42 \%)$, glutamic acid $(16 \%)$ and arginine $(15 \%)$ were on average the most abundant amino acids. Similarly, in the size fraction $2.5-10 \mu \mathrm{m}$ glutamine $(29 \%)$, arginine $(15 \%)$ and glutamic acid $(12 \%)$ were dominant, followed by proline $(7 \%)$, serine $(7 \%)$ and alanine $(7 \%)$. In the largest size fraction $>10 \mu \mathrm{m}$ proline $(36 \%)$, arginine $(21 \%)$, glutamine $(10 \%)$ and glutamic acid $(9 \%)$ were the most dominant ones. Our results are in agreement with several studies demonstrating that glycine, arginine, serine, alanine, proline and glutamine are the most commonly abundant FAAs in aerosols (Barbaro et al., 2011, 2015; Samy et al., 2011, 2013; Scalabrin et al., 2012; Violaki and Mihalopoulos, 2010; Zhang and Anastasio, 2003), although the relative abundances vary depending on location, season and particle size fraction (Matos et al., 2016).

\subsection{Seasonal variation and size distribution of microorganisms}

A distinct monthly variation in bacterial DNA abundance in different filter size fractions was observed (ANOVA, $p<$ $0.01)$. During early spring, bacterial DNA was accumulated mainly in the size fraction $>10 \mu \mathrm{m}(\sim 64 \%$, Fig. S4b). Oppositely, in late spring the highest numbers of bacteria were detected in the size fraction $1-2.5 \mu \mathrm{m}$, whereas during summer highest numbers of bacteria were discovered in the size fraction 2.5-10 $\mu \mathrm{m}$ (Fig. 2a). During summer, bacteria were mainly present in the size faction $2.5-10 \mu \mathrm{m}$, which covered on average $\sim 57 \%$ of the total bacteria amount. In general, most of the bacteria were observed in the size fractions 12.5 and $2.5-10 \mu \mathrm{m}$, and fewer bacterial cells were found in the size fraction $>10 \mu \mathrm{m}$. However, on average the abundances did not differ significantly in different size fractions (ANOVA, $p=0.494$ ). The size distribution observed is in line with that of Burrows et al. (2009b), who summarized that the median aerodynamic diameter of particles containing bacteria is $4 \mu \mathrm{m}$ at continental sites.

The abundance of Pseudomonas varied with statistical significance between different months (ANOVA, $p<0.05$ ) and between different size fractions (ANOVA, $p<0.001$ ). Pseudomonas was mainly present $(\sim 70 \%)$ in the smallest particle size fraction $(1-2.5 \mu \mathrm{m})$ throughout the year (Figs. $2 b$ and S4c). The accumulation of Pseudomonas in the smallest size fraction is in line with the small aerodynamic size $(<1 \mu \mathrm{m})$ of common Pseudomonas species (Chang et al., 2013; Möhler et al., 2008; Pietsch et al., 2015). Overall, the relative amount of Pseudomonas from all bacteria was highest in the size fraction 1-2.5 $\mu \mathrm{m}$ (Fig. S6), being highest in late winter $(28 \%)$, early spring $(15 \%)$ and autumn $(23 \%)$. Interestingly, in February the relative amount of Pseudomonas DNA of the total bacterial DNA was $17 \%$ of total particles (Fig. S6).

The amount of fungal DNA detected in different size fractions varied with statistical significance (ANOVA, $p<0.05$ ). The fungal DNA was predominantly observed in the particle size fraction $2.5-10 \mu \mathrm{m}$, which accounted for on average $\sim 58 \%$ of the total fungal concentration. The monthly variation in fungal DNA abundance was also statistically significant (ANOVA, $p<0.001$ ). During May and early June, the fungal DNA was mainly accumulated in the size fraction 1$2.5 \mu \mathrm{m}(\sim 67 \%$, Fig. S4d). In late summer, fungal DNA was detected at its highest level in the size fraction $2.5-10 \mu \mathrm{m}$ (Fig. 3), and overall $\sim 66 \%$ was accumulated in this size fraction during the summer months. Fungal spores are frequently observed in aerosols in the size range of $2-10 \mu \mathrm{m}$ (Després et al., 2012). Our observations are consistent with these literature values.

\subsection{Overview of meteorological factors and sources}

The effect of local meteorological factors on the concentration levels of FAAs and microorganism was studied by means of correlation analysis and a summary of results is shown in Fig. 4. Our results reflect rather long-term seasonal effects (more details in the Supplement), due to the time resolution of sampling. Thus, as expected, the key meteorological factors explaining the observed concentration levels were air temperature, soil temperature, gross primary production and radiation (Figs. S7 and S8). In general, we believe that the positive correlation observed between FAAs and microorganism abundances with the above-mentioned meteorological variables is closely related to growing season and seasonality, rather than being a decisive effect. These observations are in good agreement with previously reported tendencies covering microorganism and different meteorological factors (Jones and Harrison, 2004; Burrows et al., 2009b; Lighthart, 2000). Soil and vegetation have been previously suggested to be the predominant sources of microorganisms in the atmosphere (Bowers et al., 2013), and our correlation results confirm these sources as discussed below.

As could be expected (Manninen et al., 2014; Schumacher et al., 2013), the lowest concentration levels of FAAs and microorganisms were detected during winter, when the air and soil temperatures were below $0{ }^{\circ} \mathrm{C}$ and the ground was covered by snow. In February, particles below $2.5 \mu \mathrm{m}$ accounted for $89 \%$ of the total FAA concentration. In these samples, glycine and alanine were the dominant amino acids. Glycine and alanine have been exploited as markers for long-range transport aerosols due to their relatively low reactivity and long half-lives in the atmospheric condensed phases (Barbaro et al., 2011, 2015; Scalabrin et al., 2012; Samy et al., 2013). As the concentration levels of microorganisms were low dur- 


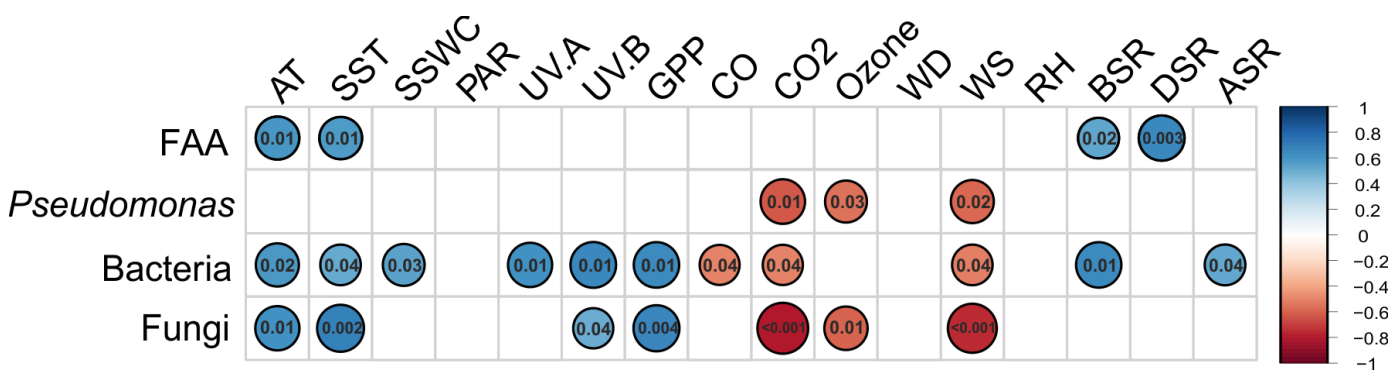

Figure 4. Summary of Spearman correlation results (total particles). The colour scale indicates positive/negative correlation ( $p$ values are shown). Abbreviations: AT, air temperature; SST, soil surface temperature; SSWC, soil surface water content; WS, wind speed; WD, wind direction; GPP, gross primary production; Ozone, ozone concentration; PAR, photosynthetically active radiation; RH, relative humidity; BSR, rainfall $72 \mathrm{~h}$ before sampling; DSR, rainfall during sampling; ASR, rainfall $168 \mathrm{~h}$ after sampling.

ing winter (Figs. 2 and 3), it is likely that the observed FAAs originated from distant sources. However, FAAs and particularly glycine have been also associated with biomass burning emissions (Samy et al., 2013; Violaki and Mihalopoulos, 2010; Zangrando et al., 2016). In Finland wood burning, which is a typical type of domestic heating in winter, is the most presumable source of over one third of the $\mathrm{PM}_{2.5}$ emissions (Laakso et al., 2003; Saarnio et al., 2012). The relative abundance of glycine in the size fraction $1-2.5 \mu \mathrm{m}$ was $85 \%$ during winter, whereas in other seasons its contribution was negligible. Thus, the observed glycine concentrations might be associated with wood-burning emissions, coming from either local or distant sources. This conclusion is supported by the observed positive correlation between glycine with $\mathrm{CO}$ concentration in the size fractions $<1 \mu \mathrm{m}(R=0.54, p<$ 0.05 , Fig. S8) and $1-2.5 \mu \mathrm{m}(R=0.80, p<0.001$, Fig. S8). Furthermore, only glycine among the FAAs showed positive correlation with PM concentration in the size fraction $1-2.5 \mu \mathrm{m}(R=0.69, p<0.01$, data not shown $)$.

FAA and bacteria concentrations increased during the spring recovery and seemed to be influenced by the increase in local biological activity. During early spring, FAAs and bacteria were mainly present in the largest size fractions (Fig. S4a and b), which may indicate the presence of pollen in aerosols, since microorganisms might be present on the surface of pollen grains (Puc, 2003). Further, Manninen et al. (2014) observed pollen to be present at SMEAR II station already before the local pollen season, most possible due to long-range transport from central Europe, where the growing season had already started. Interestingly though, during our sampling periods the back-trajectory analysis results showed air masses arriving primarily from Scandinavia and northern Europe instead of central Europe. This could imply that the larger-sized particles are originating locally from some early pollinator rather than being transported over a long range. In addition, we observed an interesting phenomenon in early March, when all FAAs, bacterial DNA and fungal DNA were present mainly in the size fraction $>$ $10 \mu \mathrm{m}$. Then the corresponding relative abundances of their total amounts were 73, 68 and 92\%, respectively. During March sampling, the air temperature was almost constantly above $0{ }^{\circ} \mathrm{C}$ for the first time in our campaign. The small increase observed in FAA and microorganism concentrations during this time might indicate that a burst in PBAP emissions can occur when the temperature increases and snow starts to melt, revealing the ground vegetation and decomposed leaf litter for the first time after winter. Similar observations have been previously made at the same site by Schumacher et al. (2013) in a study covering fluorescent biological aerosol particles (FBAPs), although they detected an increase in FBAP concentrations in November after the first snowfall and snowmelt event.

The concentrations of FAAs and bacteria reached their maximum levels during the local pollen season peak in May (Figs. 1 and 2). Elevated amino acid concentrations have also been observed during springtime in other locations and are suspected to be influenced by pollen (Barbaro et al., 2011; Zhang et al., 2002). In our study, especially proline and arginine concentrations increased during the pollen season peak. These amino acids have been shown to contribute significantly to the total amino acid content of birch pollen (Özler et al., 2009). In this study, the FAA concentrations increased in all the size fractions (Fig. 1), possibly due to rupture of relatively large $(\sim 30 \mu \mathrm{m})$ pollen grains (Taylor et al., 2004; Visez et al., 2015), supported by visibly yellow impactor plates in all the size fractions. During the peak in FAA and bacteria concentrations, the air masses were arriving in Hyytiälä from eastern Europe and the Baltic Sea. Due to the absence of pollinating species in the sea region, the observed high concentration levels of FAAs and bacteria could be mainly explained by local sources in the boreal forest. This is corroborated by the presence of methionine, cysteine and tryptophan only in these aerosol samples. Particularly these amino acids are known to be highly reactive with short half-lives in the atmospheric condensed phases (Scalabrin et al., 2012; Milne and Zika, 1993; McGregor and Anastasio, 2001). Thus, the local pollen season likely explains our observations, although other factors may partly 
contribute. For example, high ozone concentration and strong $\mathrm{UV}$ radiation were recorded during this time period, and in some studies ozone has been demonstrated to promote the decomposition of protein and peptides into free amino acids increasing the FAA concentrations (Samy et al., 2013; Mumford et al., 1972). Positive correlation was observed between FAA concentration in the size fraction $>10 \mu \mathrm{m}$ with ozone $(R=0.58, p<0.05$, Fig. S8), which was mainly attributed to coinciding peaks in concentration levels during pollen season.

Opposite to FAA concentrations being highest in the largest size fractions, bacterial DNA abundance was highest in the size fraction 1-2.5 $\mu \mathrm{m}$ during the pollen season peak. As spring proceeds, new foliage growth enables a larger surface area for epiphytic bacteria to occupy and grow on. Bacterial cells may be lifted from leaves into the air on pollen (Jones and Harrison, 2004), which may explain the peak in bacterial abundances during this season. Bacteria may be present in the air as individual cells, clumps of cells or attached to other particles, such as pollen grains and leaf fragments. We propose that, during the local pollen season and under favourable meteorological conditions, it is possible to observe a significant increase in bacterial concentrations. However, most likely the magnitude of this increase varies from year to year and is also closely related to varying pollen abundances.

Although we assume that the elevated bacterial DNA abundances are mainly related to pollen and vegetation during spring, other sources might contribute as well. For example, soil water content and bacteria concentration correlated positively in the size fractions $1-2.5 \mu \mathrm{m}(R=0.53, p<$ 0.05 , Fig. S7) and $>10 \mu \mathrm{m}(R=0.57, p<0.05$, Fig. S7). After snow melts, the soil moisture increase enhances the bacterial/microbial growth (Burrows et al., 2009b). When spring proceeds and air and soil temperatures increase, the relatively dry soil surface layer might enable the dispersal of bacteria via soil resuspension. Similarly, some studies indicate that soil-derived bacteria dominate during springtime (Rathnayake et al., 2017), while others indicate that soil sources dominate during late summer and autumn (Bowers et al., 2013). In addition, rainfall may promote the bacterial growth on vegetation surfaces, leading to increased population sizes, which may become airborne following rainfall (Bigg et al., 2015). We observed positive correlation between bacteria concentrations in the size fraction $1-2.5 \mu \mathrm{m}$ with rainfall recorded $72 \mathrm{~h}$ before the sampling $(R=0.64$, $p<0.01$, Fig. S7). Based on previous reports related to the relationship between rainfall and PBAPs (Huffman et al., 2013; Prenni et al., 2013; Gosselin et al., 2016; Rathnayake et al., 2017; Morris et al., 2016; Bigg et al., 2015), our results corroborate the positive effect of bacteria abundances following rainfall.

The abundance and relative size distribution of fungal DNA varied seasonally and started to increase in summer (Fig. 3). The relative distribution of fungal DNA to differ- ent size fractions correlated with the relative humidity $(R=$ $-0.53, P=0.035$ for $1-2.5 \mu \mathrm{m}$ and $R=0.45, P=0.081$ for $2.5-10 \mu \mathrm{m}$, data not shown). The lower the relative humidity was, the more fungi were accumulated in the smallest size fraction. Since fungal cells are typically larger than $2.5 \mu \mathrm{m}$, the observed fungal DNA in the $1-2.5 \mu \mathrm{m}$ fractions during early summer is probably originated from the spores of moulds or ruptured cells (Reponen et al., 2001). In addition, the size of fungal spores has been found to depend on the relative humidity, i.e. higher the relative humidity is, the larger the spores are (Reponen et al., 1996; Madsen, 2012). The spores of basidiomycete fungi are in general larger than those of ascomycete (Reponen et al., 2001; Manninen et al., 2014; Hussein et al., 2013; Fröhlich-Nowoisky et al., 2012), and the basidiomycete fungi are known to sporulate mainly during autumn when the relative humidity is high (Kauserud et al., 2011). Further, in the previous study by Manninen et al. (2014) the spores of Basidiomycota dominated the phylum-level distribution of fungal spores in the autumn. Our results where fungal DNA accumulated in the $2.5-10 \mu \mathrm{m}$ size fraction during autumn are in agreement with this study. Consequently, the annual size distribution of fungi can be expected to be similar from year to year in the boreal forest.

Opposite to the trend of fungi, FAA and bacterial DNA concentrations decreased after the spring pollen season peak. It is noteworthy that both bacterial and fungal DNA were accumulated during the mid-summer to early autumn in the particle size fraction $2.5-10 \mu \mathrm{m}$ (Fig. S4b and d). In summer, the air masses arrived Hyytiälä mainly from the Scandinavia and Baltic Sea regions. In early August the air masses reached Hyytiälä from a large forest fire region in Sweden. Interestingly, glycine derived from our samples was detected in relatively high concentrations $\left(\sim 2.9 \mathrm{ng} \mathrm{m}^{-3}\right)$ in the size fraction $<1 \mu \mathrm{m}$. This observation supports the hypothesis that the presence of glycine is partially related to biomass burning emissions and long-range transport. However, no distinct effects on the origin of air masses were seen in the levels of FAAs or microorganisms. Although long-range transport cannot be completely ruled out, the accumulation of bacteria and fungi in the particle size fraction $2.5-10 \mu \mathrm{m}$ suggests that primarily local forest or nearby sources affect the concentration levels of microorganisms during summer. For example, leaf-associated bacteria are known to contribute to the total bacterial amount during summer (Bowers et al., 2013). Statistically significant correlation was observed between gross primary production $(R=0.79$, $P<0.001$, Fig. S7) and photosynthetically active radiation $(R=0.69, P<0.01$, Fig. S7) with bacteria in the size fraction $2.5-10 \mu \mathrm{m}$, possibly indicating the importance of vegetation especially during summer and the growing season.

The abundance of Pseudomonas was detected at its highest level in early October in the size fraction 1-2.5 $\mu \mathrm{m}$, when it was 2-fold higher than in other months (Fig. 2b). It is suggested that an increase in the Pseudomonas syringae population size on vegetation may occur during or after rainfall (Hi- 
rano et al., 1996; Bigg et al., 2015; Morris et al., 2016). Even though no correlation was observed between average rainfall recorded before or during sampling with Pseudomonas on an annual scale, we identified interesting separate individual rainfall events. The maximum single rainfall event was recorded within $72 \mathrm{~h}$ before the above-mentioned early October sampling (Fig. S9). As far as we could tell, this was the main exception in meteorological conditions during the period studied, i.e. the only factor potentially explaining the observed increase in Pseudomonas concentration. Further, the back-trajectory analysis results showed air masses arriving from Norwegian Sea and North Sea via the Scandinavian Mountains, and to our knowledge these areas do not contain sources that could explain the increase in Pseudomonas concentration. When considering the other maximum rainfall events recorded before sampling, two out of three of the summer-autumn maximum events coincided with high Pseudomonas concentrations (Fig. S9). These findings corroborate the evidence of a potential relationship between rainfall and Pseudomonas. However, the lack of statistically significant correlation suggests that other factors are contributing to observed variation in Pseudomonas abundance.

Overall, considering the effect of rainfall on the levels of bacteria, fungi and FAAs, some interesting patterns were observed. As mentioned earlier, the bacterial DNA concentration in size fraction $1-2.5 \mu \mathrm{m}$ correlated with rainfall recorded prior to sampling. Further, we observed positive correlation between FAA concentration and rainfall during sampling in the size fractions $1-2.5 \mu \mathrm{m}(R=0.53, p=$ 0.0502 , data not shown $)$ and $2.5-10 \mu \mathrm{m}(R=0.70, p<0.01$, Fig. S8). Interestingly, bacterial DNA and fungal DNA abundances correlated positively in the size fraction $2.5-10 \mu \mathrm{m}$ with rainfall recorded $168 \mathrm{~h}$ after sampling $(R=0.63, p<$ 0.01 and $R=0.53, p<0.05$, respectively; Fig. S7). There is some evidence that cloud-active particles larger than $\sim 1 \mu \mathrm{m}$ are biological in origin (Haga et al., 2014; Hassett et al., 2015; Mason et al., 2016; Möhler et al., 2007), and in mixedphase cloud conditions, PBAPs may play an important role in triggering rainfall. Collectively, the different correlations observed between rainfall and PBAP components suggest that a potential feedback mechanism may persist at the boreal forest. This conclusion is based on the assumption that the recorded rainfall events after sampling were produced at least partially on a local scale and that the meteorological factors were favourable to formation of rainfall. We acknowledge that the positive correlation observed between microorganism abundances with rainfall recorded following sampling may be causal in nature. However, in light of the recent findings, the possibility of a feedback mechanisms cannot be ignored (Bigg et al., 2015; Morris et al., 2016; Huffman et al., 2013). Nonetheless, additional high-time-resolution and long-term measurements are needed to confirm the observations presented in this research.

\section{Conclusions}

Considering the observations made in this and previous studies (Manninen et al., 2014; Schumacher et al., 2013), some general conclusions related to PBAP abundances and size distribution at the boreal forest site can be drawn. Correlation with meteorological parameters might indicate biosphereatmosphere interactions through PBAPs with possible climate effects. In early spring, PBAP components are mainly accumulated in the size fractions $>10 \mu \mathrm{m}$. According to our results, the spring pollen season has an impact on the pollen levels as well as on the bacterial abundances. Elevated PBAP abundances occur during the pollen season (Manninen et al., 2014 ), and based on our estimation even up to $\sim 77 \%$ of total PM may be of biological origin (see Supplement for details). Even though our estimation is highly uncertain, the magnitude of biological cloud-active particles during this period may be atmospherically relevant (Diehl et al., 2002, 2001; Pummer et al., 2012, 2015). The importance of rainfall was observed in this study as well as to some extent in previous studies conducted at the same site (Manninen et al., 2014; Schumacher et al., 2013). Positive correlation was observed between PBAP component abundances with rainfall recorded before and during sampling as well as with rainfall recorded after sampling. During late summer and autumn, the accumulation of PBAPs in the size fraction $2.5-10 \mu \mathrm{m}$ was evident (Fig. S4). In autumn the relative amount of biomass in PM was estimated to be around $\sim 10 \%$ (Supplement). Modelling studies have suggested that microorganisms may play an important role in the hydrological cycle in the boreal region (Sesartic et al., 2012, 2013). However, the magnitude of upward lifting of microorganisms remains to be solved, and thus our results are preliminary in nature and need to be confirmed.

Data availability. Data used in this work are available from the authors upon request (evgeny.parshintsev@helsinki.fi).

\section{The Supplement related to this article is available online at https://doi.org/10.5194/acp-17-13089-2017- supplement.}

Author contributions. AH, OMS, JH, JB, MLR, and JP designed the experiments. AH, OMS, and JP carried them out. $\mathrm{AH}$ and OMS performed the statistical analysis. AH and JP prepared the manuscript with contributions from all co-authors.

Competing interests. The authors declare that they have no conflict of interest. 
Acknowledgements. The financial support of the Academy of Finland Centre of Excellence programme (project no. 272041, J. Parshintsev, M. L. Riekkola, A. Helin) and research project no. 292699 (O. M. Sietiö, J. Heinonsalo) are gratefully acknowledged. The technical staff of the SMEAR II station are thanked for their valuable help. The Magnus Ehrnrooth Foundation (J. Parshintsev) and University of Helsinki Doctoral Program in Microbiology and Biotechnology (MBDP) (O. M. Sietiö) are thanked for support. Geoffroy Duporté is acknowledged for back-trajectory analysis. Merck Life Science is thanked for providing ZIC-cHILIC columns.

Edited by: Alex Huffman

Reviewed by: two anonymous referees

\section{References}

Barbaro, E., Zangrando, R., Moret, I., Barbante, C., Cescon, P., and Gambaro, A.: Free amino acids in atmospheric particulate matter of Venice, Italy, Atmos. Environ., 45, 5050-5057, 2011.

Barbaro, E., Zangrando, R., Vecchiato, M., Piazza, R., Cairns, W. R. L., Capodaglio, G., Barbante, C., and Gambaro, A.: Free amino acids in Antarctic aerosol: potential markers for the evolution and fate of marine aerosol, Atmos. Chem. Phys., 15, 5457-5469, https://doi.org/10.5194/acp-15-5457-2015, 2015.

Bauer, H., Claeys, M., Vermeylen, R., Schueller, E., Weinke, G., Berger, A., and Puxbaum, H.: Arabitol and mannitol as tracers for the quantification of airborne fungal spores, Atmos. Environ., 42, 588-593, 2008.

Bigg, E. K., Soubeyrand, S., and Morris, C. E.: Persistent aftereffects of heavy rain on concentrations of ice nuclei and rainfall suggest a biological cause, Atmos. Chem. Phys., 15, 2313-2326, https://doi.org/10.5194/acp-15-2313-2015, 2015.

Bowers, R. M., Clements, N., Emerson, J. B., Wiedinmyer, C., Hannigan, M. P., and Fierer, N.: Seasonal variability in bacterial and fungal diversity of the near-surface atmosphere, Environ. Sci. Technol., 47, 12097-12106, 2013.

Burrows, S. M., Butler, T., Jöckel, P., Tost, H., Kerkweg, A., Pöschl, U., and Lawrence, M. G.: Bacteria in the global atmosphere - Part 2: Modeling of emissions and transport between different ecosystems, Atmos. Chem. Phys., 9, 9281-9297, https://doi.org/10.5194/acp-9-9281-2009, 2009a.

Burrows, S. M., Elbert, W., Lawrence, M. G., and Pöschl, U.: Bacteria in the global atmosphere - Part 1: Review and synthesis of literature data for different ecosystems, Atmos. Chem. Phys., 9, 9263-9280, https://doi.org/10.5194/acp-9-9263-2009, $2009 \mathrm{~b}$.

Chang, C. W., Li, S. Y., Huang, S. H., Huang, C. K., Chen, Y. Y., and Chen, C. C.: Effects of ultraviolet germicidal irradiation and swirling motion on airborne Staphylococcus aureus, Pseudomonas aeruginosa and Legionella pneumophila under various relative humidities, Indoor Air, 23, 74-84, 2013.

Deguillaume, L., Leriche, M., Amato, P., Ariya, P. A., Delort, A.M., Pöschl, U., Chaumerliac, N., Bauer, H., Flossmann, A. I., and Morris, C. E.: Microbiology and atmospheric processes: chemical interactions of primary biological aerosols, Biogeosciences, 5, 1073-1084, https://doi.org/10.5194/bg-5-1073-2008, 2008.

Després, V. R., Nowoisky, J. F., Klose, M., Conrad, R., Andreae, M. O., and Pöschl, U.: Characterization of primary biogenic aerosol particles in urban, rural, and high-alpine air by DNA sequence and restriction fragment analysis of ribosomal RNA genes, Biogeosciences, 4, 1127-1141, https://doi.org/10.5194/bg-4-11272007, 2007.

Després, V. R., Huffman, J. A., Burrows, S. M., Hoose, C., Safatov, A. S., Buryak, G., Fröhlich-Nowoisky, J., Elbert, W., Andreae, M. O., and Pöschl, U.: Primary biological aerosol particles in the atmosphere: a review, Tellus B, 64, 15598, https://doi.org/103402/tellusb.v64i015598, 2012.

Diehl, K., Quick, C., Matthias-Maser, S., Mitra, S. K., and Jaenicke, R.: The ice nucleating ability of pollen: Part I: Laboratory studies in deposition and condensation freezing modes, Atmos. Res., 58, 75-87, 2001.

Diehl, K., Matthias-Maser, S., Jaenicke, R., and Mitra, S. K.: The ice nucleating ability of pollen: Part II. Laboratory studies in immersion and contact freezing modes, Atmos. Res., 61, 125-133, 2002.

Draxler, R. R. and Hess, G.: An overview of the HYSPLIT_4 modelling system for trajectories, Aust. Meteorol. Mag., 47, 295308, 1998.

Elbert, W., Taylor, P. E., Andreae, M. O., and Pöschl, U.: Contribution of fungi to primary biogenic aerosols in the atmosphere: wet and dry discharged spores, carbohydrates, and inorganic ions, Atmos. Chem. Phys., 7, 4569-4588, https://doi.org/10.5194/acp-74569-2007, 2007.

Estillore, A. D., Trueblood, J. V., and Grassian, V. H.: Atmospheric chemistry of bioaerosols: heterogeneous and multiphase reactions with atmospheric oxidants and other trace gases, Chem. Sci., 7, 6604-6616, 2016.

Fierer, N., Jackson, J. A., Vilgalys, R., and Jackson, R. B.: Assessment of soil microbial community structure by use of taxonspecific quantitative PCR assays, Appl. Environ. Microb., 71, 4117-4120, 2005.

Fröhlich-Nowoisky, J., Pickersgill, D. A., Després, V. R., and Pöschl, U.: High diversity of fungi in air particulate matter, P. Natl. Acad. Sci. USA, 106, 12814-12819, 2009.

Fröhlich-Nowoisky, J., Burrows, S. M., Xie, Z., Engling, G., Solomon, P. A., Fraser, M. P., Mayol-Bracero, O. L., Artaxo, P., Begerow, D., Conrad, R., Andreae, M. O., Després, V. R., and Pöschl, U.: Biogeography in the air: fungal diversity over land and oceans, Biogeosciences, 9, 1125-1136, https://doi.org/10.5194/bg-9-1125-2012, 2012.

Fröhlich-Nowoisky, J., Kampf, C. J., Weber, B., Huffman, J. A., Pöhlker, C., Andreae, M. O., Lang-Yona, N., Burrows, S. M., Gunthe, S. S., and Elbert, W.: Bioaerosols in the Earth system: climate, health, and ecosystem interactions, Atmos. Res., 182, 346-376, 2016.

Georgakopoulos, D. G., Després, V., Fröhlich-Nowoisky, J., Psenner, R., Ariya, P. A., Pósfai, M., Ahern, H. E., Moffett, B. F., and Hill, T. C. J.: Microbiology and atmospheric processes: biological, physical and chemical characterization of aerosol particles, Biogeosciences, 6, 721-737, https://doi.org/10.5194/bg-6721-2009, 2009.

Gosselin, M. I., Rathnayake, C. M., Crawford, I., Pöhlker, C., Fröhlich-Nowoisky, J., Schmer, B., Després, V. R., Engling, G., Gallagher, M., Stone, E., Pöschl, U., and Huffman, J. A.: Fluorescent bioaerosol particle, molecular tracer, and fungal spore concentrations during dry and rainy periods in a semi-arid forest, Atmos. Chem. Phys., 16, 15165-15184, https://doi.org/10.5194/acp-16-15165-2016, 2016. 
Haga, D. I., Burrows, S. M., Iannone, R., Wheeler, M. J., Mason, R. H., Chen, J., Polishchuk, E. A., Pöschl, U., and Bertram, A. K.: Ice nucleation by fungal spores from the classes Agaricomycetes, Ustilaginomycetes, and Eurotiomycetes, and the effect on the atmospheric transport of these spores, Atmos. Chem. Phys., 14, 8611-8630, https://doi.org/10.5194/acp-14-8611-2014, 2014.

Hari, P. and Kulmala, M.: Station for Measuring EcosystemAtmosphere Relations (SMEAR II), Boreal Environ. Res., 10, 315-322, 2005.

Harrel, F. E: Hmisc: Harrell miscellaneous, R package version 4.02, available at: https://CRAN.R-project.org/package=Hmisc (last access: 27 March 2017), 2016.

Hassett, M. O., Fischer, M. W., and Money, N. P.: Mushrooms as rainmakers: how spores act as nuclei for raindrops, Plos One, 10, e0140407, https://doi.org/10.1371/journal.pone.0140407, 2015.

Hirano, S. S., Baker, L. S., and Upper, C. D.: Raindrop momentum triggers growth of leaf-associated populations of Pseudomonas syringae on field-grown snap bean plants, Appl. Environ. Microb., 62, 2560-2566, 1996.

Hock, N., Schneider, J., Borrmann, S., Römpp, A., Moortgat, G., Franze, T., Schauer, C., Pöschl, U., Plass-Dülmer, C., and Berresheim, H.: Rural continental aerosol properties and processes observed during the Hohenpeissenberg Aerosol Characterization Experiment (HAZE2002), Atmos. Chem. Phys., 8, 603-623, https://doi.org/10.5194/acp-8-603-2008, 2008.

Huffman, J. A., Prenni, A. J., DeMott, P. J., Pöhlker, C., Mason, R. H., Robinson, N. H., Fröhlich-Nowoisky, J., Tobo, Y., Després, V. R., Garcia, E., Gochis, D. J., Harris, E., MüllerGermann, I., Ruzene, C., Schmer, B., Sinha, B., Day, D. A., Andreae, M. O., Jimenez, J. L., Gallagher, M., Kreidenweis, S. M., Bertram, A. K., and Pöschl, U.: High concentrations of biological aerosol particles and ice nuclei during and after rain, Atmos. Chem. Phys., 13, 6151-6164, https://doi.org/10.5194/acp13-6151-2013, 2013.

Hussein, T., Norros, V., Hakala, J., Petäjä, T., Aalto, P. P., Rannik, Ü., Vesala, T., and Ovaskainen, O.: Species traits and inertial deposition of fungal spores, J. Aerosol Sci., 61, 81-98, 2013.

Jaenicke, R.: Abundance of cellular material and proteins in the atmosphere, Science, 308, 73-73, 2005

Jones, A. M. and Harrison, R. M.: The effects of meteorological factors on atmospheric bioaerosol concentrations - a review, Sci. Total Environ., 326, 151-180, 2004.

Junninen, H., Lauri, A., Keronen, P., AaIto, P., HiItunen, V., Hari, P., and KuImaIa, M.: Smart-SMEAR: on-line data exploration and visualization tool tor SMEAR stations, Boreal Environ. Res., 14, 447-457, 2009.

Kauserud, H., Heegaard, E., Halvorsen, R., Boddy, L., Høiland, K., and Stenseth, N. C.: Mushroom's spore size and time of fruiting are strongly related: is moisture important?, Biology Lett., 7, 273-276, 2011.

Kuuskeri, J., Häkkinen, M., Laine, P., Smolander, O.-P., Tamene, F., Miettinen, S., Nousiainen, P., Kemell, M., Auvinen, P., and Lundell, T.: Time-scale dynamics of proteome and transcriptome of the white-rot fungus Phlebia radiata: growth on spruce wood and decay effect on lignocellulose, Biotechnol. Biofuels, 9, 192, https://doi.org/101186/s13068-016-0608-9, 2016.

Laakso, L., Hussein, T., Aarnio, P., Komppula, M., Hiltunen, V., Viisanen, Y., and Kulmala, M.: Diurnal and annual characteristics of particle mass and number concentrations in urban, rural and Arctic environments in Finland, Atmos. Environ., 37, 26292641, 2003.

Lighthart, B.: Mini-review of the concentration variations found inthe alfresco atmospheric bacterial populations, Aerobiologia, 16, 7-16, 2000.

Madsen, A. M.: Effects of airflow and changing humidity on the aerosolization of respirable fungal fragments and conidia of Botrytis cinerea, Appl. Environ. Microb., 78, 3999-4007, 2012.

Manninen, H. E., Bäck, J., Sihto-Nissilä, S.-L., Huffman, J. A., Pessi, A.-M., Hiltunen, V., Aalto, P. P., Hidalgo Fernández, P. J., Hari, P., and Saarto, A.: Patterns in airborne pollen and other primary biological aerosol particles (PBAP), and their contribution to aerosol mass and number in a boreal forest, Boreal Environ. Res., 19, 383-405, 2014.

Mason, R. H., Si, M., Chou, C., Irish, V. E., Dickie, R., Elizondo, P., Wong, R., Brintnell, M., Elsasser, M., Lassar, W. M., Pierce, K. M., Leaitch, W. R., MacDonald, A. M., Platt, A., ToomSauntry, D., Sarda-Estève, R., Schiller, C. L., Suski, K. J., Hill, T. C. J., Abbatt, J. P. D., Huffman, J. A., DeMott, P. J., and Bertram, A. K.: Size-resolved measurements of ice-nucleating particles at six locations in North America and one in Europe, Atmos. Chem. Phys., 16, 1637-1651, https://doi.org/10.5194/acp16-1637-2016, 2016.

Matos, J. T., Duarte, R. M., and Duarte, A. C.: Challenges in the identification and characterization of free amino acids and proteinaceous compounds in atmospheric aerosols: a critical review, TrAC Trends, Anal. Chem., 75, 97-107, 2016.

McGregor, K. G. and Anastasio, C.: Chemistry of fog waters in California's Central Valley: 2. photochemical transformations of amino acids and alkyl amines, Atmos. Environ., 35, 1091-1104, 2001.

Milne, P. J. and Zika, R. G.: Amino acid nitrogen in atmospheric aerosols: occurrence, sources and photochemical modification, J. Atmos. Chem., 16, 361-398, 1993.

Möhler, O., DeMott, P. J., Vali, G., and Levin, Z.: Microbiology and atmospheric processes: the role of biological particles in cloud physics, Biogeosciences, 4, 1059-1071, https://doi.org/10.5194/bg-4-1059-2007, 2007.

Möhler, O., Georgakopoulos, D. G., Morris, C. E., Benz, S., Ebert, V., Hunsmann, S., Saathoff, H., Schnaiter, M., and Wagner, R.: Heterogeneous ice nucleation activity of bacteria: new laboratory experiments at simulated cloud conditions, Biogeosciences, 5, 1425-1435, https://doi.org/10.5194/bg-5-1425-2008, 2008.

Morris, C. E., Sands, D. C., Bardin, M., Jaenicke, R., Vogel, B., Leyronas, C., Ariya, P. A., and Psenner, R.: Microbiology and atmospheric processes: research challenges concerning the impact of airborne micro-organisms on the atmosphere and climate, Biogeosciences, 8, 17-25, https://doi.org/10.5194/bg-8-17-2011, 2011.

Morris, C. E., Soubeyrand, S., Bigg, E. K., Creamean, J. M., and Sands, D. C.: Mapping rainfall feedback to reveal the potential sensitivity of precipitation to biological aerosols, B. Am. Meteorol. Soc., https://doi.org/10.1175/BAMS-D-15-002931, in press, 2016.

Mumford, R. A., Lipke, H., Laufer, D. A., and Feder, W. A.: Ozoneinduced changes in corn pollen, Environ. Sci. Technol., 6, 427430, 1972.

Oksanen, J. F., Blanchet, G., Kindt, R., Legendre, P., Minchin, P. R., O’Hara, R. B., Simpson, G. L., Solymos, P., Henry, M., 
Stevens, M. H. H., and Wagner, H.: vegan: Community Ecology Package, R package version 2.3-3, available at: https://CRAN. R-project.org/package=vegan (last access: 27 March 2017), 2016.

Özler, H., Pehlivan, S., and Bayrak, F.: Analysis of free amino acid and total protein content in pollen of some allergenic taxa, Asian J. Plant Sci., 8, 308-312, https://doi.org/10.3923/ajps.2009308312, 2009.

Pietsch, R. B., David, R. F., Marr, L. C., Vinatzer, B., and Schmale III, D. G.: Aerosolization of two strains (ice + and ice -) of Pseudomonas syringae in a collison nebulizer at different temperatures, Aerosol Sci. Tech., 49, 159-166, 2015.

Pöschl, U., Martin, S., Sinha, B., Chen, Q., Gunthe, S., Huffman, J., Borrmann, S., Farmer, D., Garland, R., and Helas, G.: Rainforest aerosols as biogenic nuclei of clouds and precipitation in the Amazon, Science, 329, 1513-1516, 2010.

Prenni, A., Tobo, Y., Garcia, E., DeMott, P., Huffman, J., McCluskey, C., Kreidenweis, S., Prenni, J., Pöhlker, C., and Pöschl, U.: The impact of rain on ice nuclei populations at a forested site in Colorado, Geophys. Res. Lett., 40, 227-231, 2013.

Puc, M.: Characterisation of pollen allergens, Ann. Agr. Env. Med., 10, 143-150, 2003.

Pummer, B. G., Bauer, H., Bernardi, J., Bleicher, S., and Grothe, H.: Suspendable macromolecules are responsible for ice nucleation activity of birch and conifer pollen, Atmos. Chem. Phys., 12, 2541-2550, https://doi.org/10.5194/acp-12-2541-2012, 2012.

Pummer, B. G., Budke, C., Augustin-Bauditz, S., Niedermeier, D., Felgitsch, L., Kampf, C. J., Huber, R. G., Liedl, K. R., Loerting, T., Moschen, T., Schauperl, M., Tollinger, M., Morris, C. E., Wex, H., Grothe, H., Pöschl, U., Koop, T., and Fröhlich-Nowoisky, J.: Ice nucleation by watersoluble macromolecules, Atmos. Chem. Phys., 15, 4077-4091, https://doi.org/10.5194/acp-15-4077-2015, 2015.

Purohit, H. J., Raje, D. V., and Kapley, A.: Identification of signature and primers specific to genus Pseudomonas using mismatched patterns of 16S rDNA sequences, BMC Bioinformatics, 4, 19, https://doi.org/10.1186/1471-2105-4-19, 2003.

Rathnayake, C. M., Metwali, N., Jayarathne, T., Kettler, J., Huang, Y., Thorne, P. S., O'Shaughnessy, P. T., and Stone, E. A.: Influence of rain on the abundance of bioaerosols in fine and coarse particles, Atmos. Chem. Phys., 17, 2459-2475, https://doi.org/10.5194/acp-17-2459-2017, 2017.

R Core Team: R: A language and environment for statistical computing, R Foundation for Statistical Computing, Vienna, Austria, available at: https://www.r-project.org/ (last access: 17 June 2017), 2016.

Reponen, T., Willeke, K., Ulevicius, V., Reponen, A., and Grinshpun, S. A.: Effect of relative humidity on the aerodynamic diameter and respiratory deposition of fungal spores, Atmos. Environ., 30, 3967-3974, 1996.

Reponen, T., Grinshpun, S., Conwell, K., Wiest, J., and Anderson, M.: Aerodynamic vs. physical size of spores: measurement and implication for respiratory deposition, Grana, 40, 119-125, 2001.

Rolph, G.: Real-time Environmental Applications and Display sYstem (READY) website, NOAA Air Resources Laboratory, Silver Spring, Md, http://www.arl.noaa.gov/ready/hysplit4.html (last access: 20 March 2017), 2003.
Saarnio, K., Niemi, J. V., Saarikoski, S., Aurela, M., Timonen, H., Teinila, K., Myllynen, M., Freyi, A., Lamberg, H., and Jokiniemi, J.: Using monosaccharide anhydrides to estimate the impact of wood combustion on fine particles in the Helsinki Metropolitan Area, Boreal Environ. Res., 17, 163-184, 2012.

Samy, S., Robinson, J., and Hays, M. D.: An advanced LC-MS (QTOF) technique for the detection of amino acids in atmospheric aerosols, Anal. Bioanal. Chem., 401, 3103-3113, 2011.

Samy, S., Robinson, J., Rumsey, I. C., Walker, J. T., and Hays, M. D.: Speciation and trends of organic nitrogen in southeastern US fine particulate matter $\left(\mathrm{PM}_{2.5}\right)$, J. Geophys. Res.Atmos., 118, 1996-2006, 2013.

Scalabrin, E., Zangrando, R., Barbaro, E., Kehrwald, N. M., Gabrieli, J., Barbante, C., and Gambaro, A.: Amino acids in Arctic aerosols, Atmos. Chem. Phys., 12, 10453-10463, https://doi.org/10.5194/acp-12-10453-2012, 2012.

Schneider, J., Freutel, F., Zorn, S. R., Chen, Q., Farmer, D. K., Jimenez, J. L., Martin, S. T., Artaxo, P., Wiedensohler, A., and Borrmann, S.: Mass-spectrometric identification of primary biological particle markers and application to pristine submicron aerosol measurements in Amazonia, Atmos. Chem. Phys., 11, 11415-11429, https://doi.org/10.5194/acp-11-11415-2011, 2011.

Schumacher, C. J., Pöhlker, C., Aalto, P., Hiltunen, V., Petäjä, T., Kulmala, M., Pöschl, U., and Huffman, J. A.: Seasonal cycles of fluorescent biological aerosol particles in boreal and semi-arid forests of Finland and Colorado, Atmos. Chem. Phys., 13, 11987-12001, https://doi.org/10.5194/acp-13-11987-2013, 2013.

Sesartic, A., Lohmann, U., and Storelvmo, T.: Bacteria in the ECHAM5-HAM global climate model, Atmos. Chem. Phys., 12, 8645-8661, https://doi.org/10.5194/acp-12-8645-2012, 2012.

Sesartic, A., Lohmann, U., and Storelvmo, T.: Modelling the impact of fungal spore ice nuclei on clouds and precipitation, Environ. Res. Lett., 8, 014029, https://doi.org/10.1088/17489326/8/1/014029, 2013.

Spracklen, D. V. and Heald, C. L.: The contribution of fungal spores and bacteria to regional and global aerosol number and ice nucleation immersion freezing rates, Atmos. Chem. Phys., 14, 90519059, https://doi.org/10.5194/acp-14-9051-2014, 2014.

Staton, S. J., Woodward, A., Castillo, J. A., Swing, K., and Hayes, M. A.: Ground level environmental protein concentrations in various ecuadorian environments: potential uses of aerosolized protein for ecological research, Ecol. Indic., 48, 389395, 2015.

Stein, A. F., Draxler, R. R., Rolph, G. D., Stunder, B. J. B., Cohen, M. D., and Ngan, F.: NOAA's HYSPLIT atmospheric transport and dispersion modeling system, B. Am. Meteorol. Soc., 96, 2059-2077, 2015.

Stoddard, S. F., Smith, B. J., Hein, R., Roller, B. R., and Schmidt, T. M.: rrnDB: improved tools for interpreting rRNA gene abundance in bacteria and archaea and a new foundation for future development, Nucleic Acids Res., 43, D593-D598, 2014.

Taylor, P., Flagan, R., Miguel, A., Valenta, R., and Glovsky, M.: Birch pollen rupture and the release of aerosols of respirable allergens, Clin. Exp. Allergy, 34, 1591-1596, 2004.

Vainio, E. J. and Hantula, J.: Direct analysis of wood-inhabiting fungi using denaturing gradient gel electrophoresis of amplified ribosomal DNA, Mycol. Res., 104, 927-936, 2000. 
Violaki, K. and Mihalopoulos, N.: Water-soluble organic nitrogen (WSON) in size-segregated atmospheric particles over the Eastern Mediterranean, Atmos. Environ., 44, 4339-4345, 2010.

Visez, N., Chassard, G., Azarkan, N., Naas, O., Sénéchal, H., Sutra, J.-P., Poncet, P., and Choël, M.: Wind-induced mechanical rupture of birch pollen: potential implications for allergen dispersal, J. Aerosol Sci., 89, 77-84, 2015.

Wei, T. and Simko, V.: corrplot: visualization of a Correlation Matrix, R package version 0.77, available at: https://CRAN. R-project.org/package $=$ corrplot (last access: 27 March 2017), 2016.

Zangrando, R., Barbaro, E., Kirchgeorg, T., Vecchiato, M., Scalabrin, E., Radaelli, M., Đorđević, D., Barbante, C., and Gambaro, A.: Five primary sources of organic aerosols in the urban atmosphere of Belgrade (Serbia), Sci. Total Environ., 571, 14411453, 2016.
Zhang, Q. and Anastasio, C.: Free and combined amino compounds in atmospheric fine particles $\left(\mathrm{PM}_{2.5}\right)$ and fog waters from Northern California, Atmos. Environ., 37, 2247-2258, 2003.

Zhang, Q., Anastasio, C., and Jimenez-Cruz, M.: Water-soluble organic nitrogen in atmospheric fine particles $\left(\mathrm{PM}_{2.5}\right)$ from northern California, J. Geophys. Res.-Atmos., 107, 4112, https://doi.org/10.1029/2001JD000870, 2002.

Zhang, T., Engling, G., Chan, C.-Y., Zhang, Y.-N., Zhang, Z.-S., Lin, M., Sang, X.-F., Li, Y., and Li, Y.-S.: Contribution of fungal spores to particulate matter in a tropical rainforest, Environ. Res. Lett., 5, 024010, https://doi.org/10.1088/1748-9326/5/2/024010, 2010.

Zhu, C., Kawamura, K., and Kunwar, B.: Organic tracers of primary biological aerosol particles at subtropical Okinawa Island in the western North Pacific Rim, J. Geophys. Res.-Atmos., 120, 5504 5523, 2015. 